Research Paper

\title{
Paracoccidioidomycosis in southern Rio Grande do Sul: A retrospective study of histopathologically diagnosed cases
}

\author{
Silvana Pereira de Souza ${ }^{1}$, Valéria Magalhães Jorge ${ }^{1,2}$, Melissa Orzechowski Xavier ${ }^{3,4}$ \\ ${ }^{1}$ Faculdade de Odontologia, Universidade Federal de Pelotas, Pelotas, RS, Brazil. \\ ${ }^{2}$ Santa Casa de Misericórdia de Pelotas, Pelotas, RS, Brazil. \\ ${ }^{3}$ Faculdade de Medicina, Universidade Federal do Rio Grande, Rio Grande, RS, Brazil. \\ ${ }^{4}$ Programa de Pós-Graduação em Ciências da Saúde, Universidade Federal do Rio Grande, Rio Grande, \\ RS, Brazil
}

Submitted: May 28, 2012; Approved: September 9, 2013.

\begin{abstract}
Paracoccidioidomycosis (PCM) is a systemic mycosis caused by the fungus Paracoccidioides brasiliensis and is endemic to Brazil. The aim of this study was to perform a retrospective analysis of the PCM cases in the countryside south of Rio Grande do Sul, Brazil. The files from four histopathology laboratories located in the city of Pelotas were obtained, and all of the epidemiological and clinical data from the PCM diagnosed cases were collected for analysis. A total of 123 PCM cases diagnosed between 1966 and 2009 were selected. Of these patients, 104 (84.5\%) were male, and 17 were female. The patients ranged from 02 to 92 years of age. Fifty-two cases $(41.9 \%)$ were obtained from the oral pathology laboratory, and the remaining 71 cases (58.1\%) were obtained from the three general pathology laboratories. Of all of the patients studied, $65.2 \%$ lived in rural zones and worked in agriculture or other related fields. Data on the evolution of this disease was available for 43 cases, and the time frame ranged from 20 to 2920 days (mean $=572.3$ days). An accurate diagnosis performed in less than 30 days only occurred in $21 \%$ of the cases. PCM is endemic to the countryside of Rio Grande do Sul. Therefore, it is recommended that PCM be included as a differential diagnosis, mainly for individuals between 30 and 60 years of age, living in rural zones and who have respiratory signs and associated-oropharyngeal lesions.
\end{abstract}

Key words: Paracoccidioides brasiliensis, epidemiology, systemic mycosis.

\section{Introduction}

Paracoccidioidomycosis (PCM) is a systemic mycosis that was first described in 1908 by Adolfo Lutz, who identified it as a South American blastomycosis. PCM is caused by Paracoccidioides brasiliensis, a dimorphic fungus that has a mycelial form at room temperature $\left(25^{\circ} \mathrm{C}\right)$ and a yeast form under conditions of parasitism $\left(37^{\circ} \mathrm{C}\right)$ (Shikanai-Yasuda et al., 2006; Ramos et al., 2008).

PCM may appear as an acute / subacute case in children and adolescents, also known as the juvenile form, or as a chronic case, which is especially common in adults. Both types of cases can result in residual PCM. The slow progressive infection primarily involves inhaling fungal pro- pagules into the lungs and tends to cause secondary lesions in the mucous membranes, lymph nodes and/or skin through hematogenous spread (Marques, 2003; ShikanaiYasuda et al., 2006).

The disease is endemic to Latin America and occurs in southern Mexico and northern Argentina. PCM cases found outside these areas are reported by patients who have visited or lived in a Latin American country. The majority of the PCM cases $(\approx 80 \%)$ are reported in Brazil, mainly in the states of São Paulo, Paraná, Rio Grande do Sul, Goiás, Rio de Janeiro and Rondônia (Palmeiro et al., 2005; Ramos et al., 2008; Colombo et al., 2011). The frequency of reported cases has also been increasing in the North and Cen-

Send correspondence to M.O. Xavier. Laboratório de Micologia, Faculdade de Medicina, Universidade Federal do Rio Grande, Campus Saúde, Visconde de Paranaguá 102, Centro, 96201-900 Rio Grande, RS, Brazil. E-mail: melissaxavier@furg.br. 
tral-West regions of the country (Paniago et al., 2003; Shikanai-Yasuda et al., 2006).

Even though paracoccidioidomycosis is endemic to Rio Grande do Sul, few studies have addressed the occurrence of this disease in the cities of the southern part of the state. This study aimed to describe the clinical and epidemiological data on the PCM diagnosed cases from the pathology labs in the city of Pelotas, RS, Brazil.

\section{Materials and Methods}

The study was carried out retrospectively by evaluating the databases from the four major pathology labs, one lab of which is odontology specific, in the city of Pelotas. This region has altitudes between 100 and $429 \mathrm{~m}$ and a humid subtropical climate that consists of warm temperate summers and cold winters with frequent frosts (an average of 20 per year). Rainfall occurs regularly throughout the year. The average annual rainfall is $1.379 \mathrm{~mm}$, and the relative humidity is high, with an annual average of approximately $80 \%$. The average temperature for the warmer months is $23^{\circ} \mathrm{C}$, and the average temperature for the colder months is $12^{\circ} \mathrm{C}$.

A survey of the total number of paracoccidioidomycosis cases diagnosed in each laboratory until the year 2010 was initially performed. These cases were confirmed by the detection of multiple budding yeast cells typical of P. brasiliensis in tissue fragments (Figure 1). All of the cases confirmed by histopathology (123 cases from 1966 to 2009) were included in this study. The following information was collected for this study using the biopsy data sheets and laboratory evaluations: age, sex, origin (rural or urban), professional activity, course of the disease, location of lesions and signs/symptoms. The data were compiled and descriptively analyzed using the program Epi Info 3.5.1.

This study was approved by the ethics committee of the institution (CEPAS-FURG 176/2011).

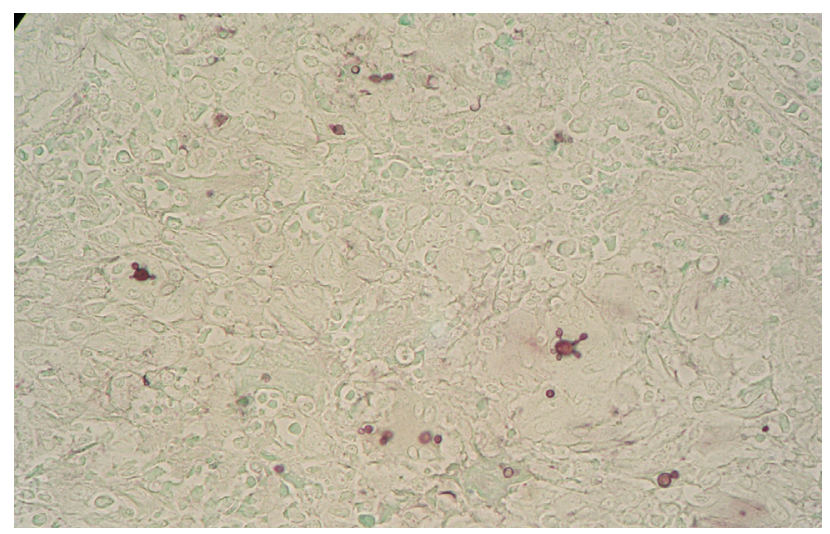

Figure 1 - Histological section of a lesion in the oral mucosa stained with Gomori-Grocott. Black dots indicate the presence of multiple budding blastoconidia characteristic of $P$. brasiliensis (400x).

\section{Results}

From the four laboratories in Pelotas included in this study, 123 patients diagnosed with PCM by histopathological examination were identified. Four of the cases have already been published as case reports (Jannke et al., 1982, 1983, 1993). All of these cases occurred within a 43-year period. The first case was recorded in 1966, and the last case was recorded in 2009. Even though this finding suggests that there is an average of three cases per year, the number of cases reported each year was not the same. Approximately $96(78 \%)$ of the PCM cases were diagnosed within the last two decades of the time period (1990 and 2000) (Figure 2).

The laboratory specializing in odontology was responsible for diagnosing 52 (41.9\%) of the PCM cases. The other 71 cases were diagnosed by the other three general pathology labs.

The 123 patients ranged between 02 and 92 years of age. Three $(2.4 \%)$ patients were between 02 and 29 years of age, $78(63.4 \%)$ patients were between 30 and 60 years of age, and $34(27.6 \%)$ patients were over 60 years of age. The age of $8(6.5 \%)$ patients was not available. Of the $123 \mathrm{pa}-$ tients, $104(84.5 \%)$ were male, and only 17 were female. Of the 17 female patients, $11(64.7 \%)$ of them were between 30 and 60 years of age.

Information on the area of origin (rural or urban) and occupation/profession was obtained for 46 patients. Of these patients, $30(65.2 \%)$ of them resided in rural areas, and their occupation involved land-related activities, especially agriculture.

Information on the city of origin was available for 50 patients. Approximately $70 \%$ of these patients were from Pelotas ( $\mathrm{n}=19)$ and Canguçu $(\mathrm{n}=16)$, the remaining patients were from Bagé $(\mathrm{n}=1)$, Cristal $(\mathrm{n}=2)$, Jaguarão $(\mathrm{n}=1)$, Pedro Osório $(\mathrm{n}=1)$, Piratini $(\mathrm{n}=2)$, Rio Grande $(\mathrm{n}=1)$, Santana da Boa Vista $(\mathrm{n}=3)$, São José do Norte $(\mathrm{n}=1)$ and São Lourenço do Sul $(\mathrm{n}=3)$ (Figure 3).

The main anatomical regions with lesions indicative of PCM and biopsied for diagnostic confirmation were the

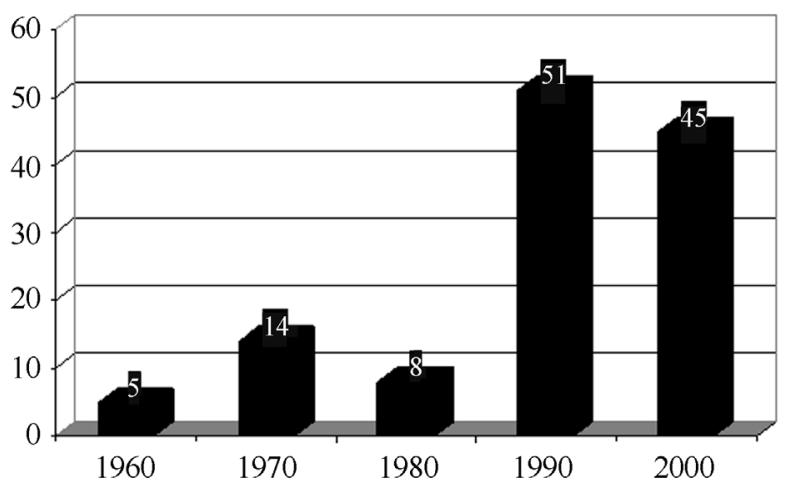

Figure 2 - Number of PCM cases diagnosed in pathology labs in Pelotas, RS, Brazil during the four decades included in the study. 
oropharyngeal mucosa $(\mathrm{n}=62)$, lower respiratory tract $(n=34)$ and the skin and/or lymph nodes $(n=14)$. In the 52 cases diagnosed from lesions from the oropharyngeal mucosa, 17 (32.6\%) of them had an associated pulmonary involvement. This type of information, however, was not available for the remaining 35 patients.

Data on the amount of time from the onset of symptoms until the date of diagnosis was obtained for 43 patients and ranged from 20 to 2920 days, with an average of 572.3 days. Of these cases, only $21 \%(9 / 43)$ were diagnosed in less than 30 days. The main clinical symptoms included pain in the oropharyngeal mucosa, lesions, coughing, weight loss, adenopathy and fever.

\section{Discussion}

This paper describes the clinical and epidemiological data on PCM patients from Pelotas and neighboring cities. The diagnosis of the 123 PCM cases evaluated in our study occurred over a 43-year period, and these cases emphasize the importance of this disease in southern Rio Grande do Sul cities despite their cold winters and frequent frost. The endemic characteristic of this disease have already been reported for cities located in other mesoregions of the state, such as Santa Maria and Porto Alegre, with the number of annual incidences ranging from 8.06 to 17.57 cases per year (Londero et al., 1978;
Londero and Ramos, 1990; Santos et al., 1999). This type of information, however, has not yet been reported for the Southeast Rio-Grandense mesoregion of Rio Grande do Sul, which is located in southern Brazil.

Considering the long incubation period for this disease (Shikanai-Yasuda et al., 2006, Colombo et al., 2011), we cannot conclude that all of these patients were infected in this mesoregion of the state, only that the disease was diagnosed there. Furthermore, we only included the PCM cases diagnosed by histopathology in this study. Other PCM cases that were diagnosed by fungal culture or serology tests were not considered in our study, and therefore, the number of cases is probably higher.

In our study, approximately $80 \%$ of PCM cases were diagnosed within the last two decades (1990 and 2000) of the time period examined. This trend is probably the result of advances made in the field of medical mycology in the 1990s in response to the AIDS epidemic. Consequently, there was an increase in the number of professionals who specialized in opportunistic fungal diseases, which lead to an increase in the suspicion and diagnosis of systemic mycoses (Ameen et al., 2010). Other possible reasons for this trend include an increase in access to health care and an increase in the number of incidences of this disease in the region. Larger studies are needed, however, to confirm these hypotheses.

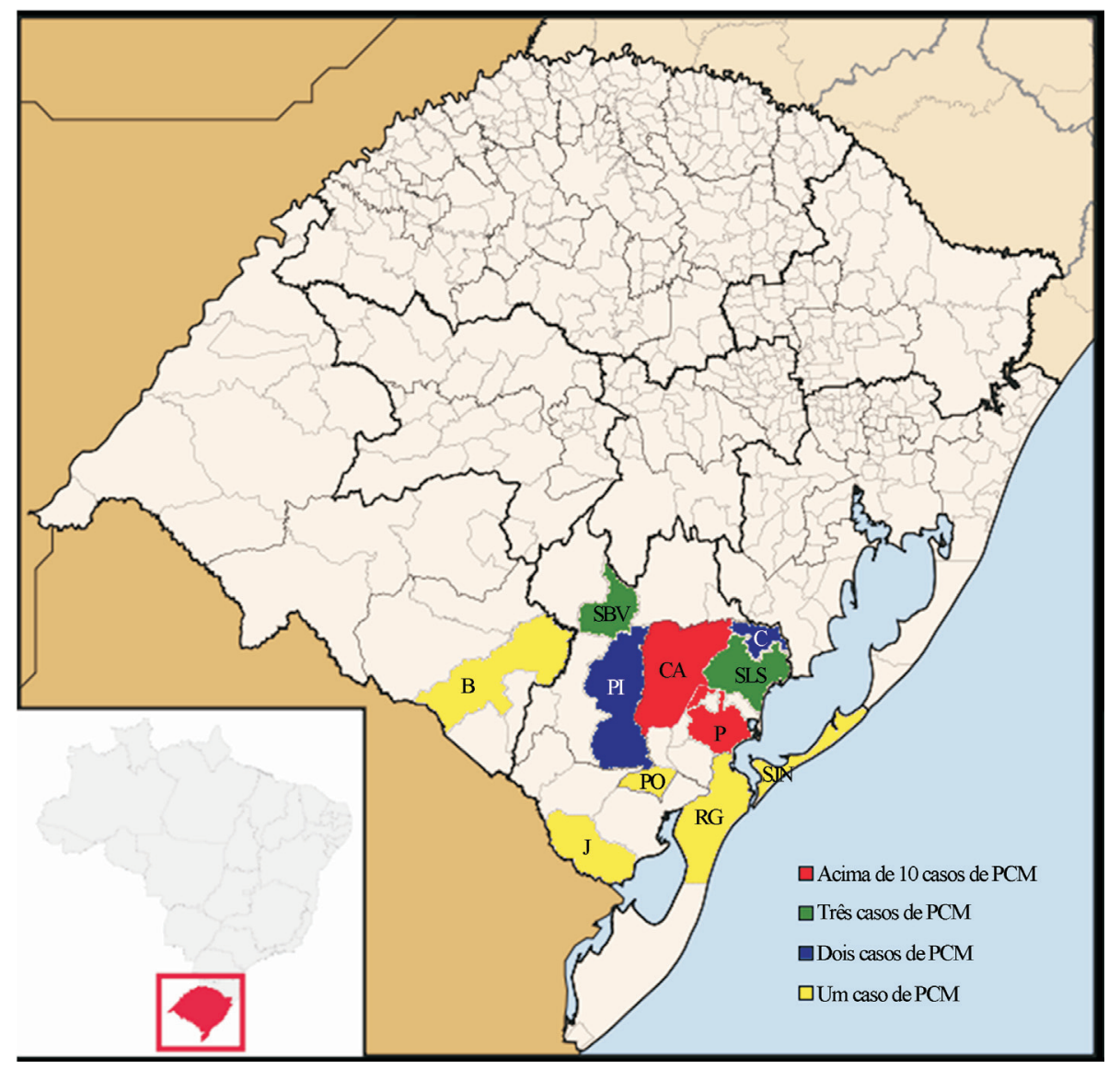

Figure 3 - Cities of origin for the patients with paracoccidioidomycosis diagnosed in pathology labs in the city of Pelotas, RS, Brazil (CA: Canguçu; P: Pelotas; SBV: Santana da Boa Vista; SLS: São Lourenço do Sul; PI: Piratini; C: Cristal; B: Bagé; J: Jaguarão; PO: Pedro Osório; RG: Rio Grande; SJN: São José do Norte). 
Most of our PCM patients were adult men who had the chronic form of this disease. The predominance of male patients is consistent with findings from studies that found male-to-female ratios between 5:1 to 16.3:1 in Mato Grosso do Sul, Brasília, São Paulo and Rio Grande do Sul (Londero and Ramos, 1990; Blotta et al., 1999; Paniago et al., 2003; Shikanai-Yasuda et al., 2006; Campos et al., 2008). This difference may be explained by a hormone protective factor in women. The presence of estrogen receptors in $P$. brasiliensis inhibits the transformation from the mycelial phase to the yeast parasitic phase of the fungus (BorgesWalmsley et al., 2002; Almeida et al., 2003; Vieira and Borsatto-Galera, 2006; Bousquet et al., 2007). If there is a hormone protective factor, then postmenopausal women should become more susceptible to PCM. The majority of the women (11/17) with diagnosed PCM in our study, however, were of fertile age, between 30 and 60 of age.

Consistent with previous findings (Verli et al., 2005; Bousquet et al., 2007), a high portion of the PCM patients, $65.2 \%$, evaluated in this study were involved in agricultural activities. Agricultural activities predispose individuals to mycosis because of their higher exposure to infectious fungal propagules. For instance, the natural habitat of $P$. brasiliensis includes forested areas with wet soils (Bousquet et al., 2007; Richini-Pereira et al., 2009). Furthermore, agribusiness is the most common economic activity in Pelotas and Canguçu, which are the cities with the highest number of cases in our study.

The oropharyngeal mucosa and lungs were the most common sites of lesions found in our study. According to previous reports, these organs are the most common organs involved in PCM (Almeida et al., 2003; Verli et al., 2005; Vieira and Borsatto-Galera, 2006). We found that almost half of our PCM cases $(41.9 \%)$ were diagnosed in the odontology pathology laboratory, which indicates that the oropharyngeal mucosa is frequently affected by this disease. Moriform stomatitis is especially characteristic of this disease. This finding indicates that the dental surgeon is an important professional in the diagnosis of PCM because patients will frequently seek medical assistance for oral lesions and not respiratory symptoms, which are erroneously associated with smoking (Araújo and Souza, 2000; Palmeiro et al., 2005; Verli et al., 2005; Vieira and BorsattoGalera, 2006). The clinical symptoms described by the patients included in our study are consistent with the symptoms described in the literature, such as pain in mucocutaneous lesions, coughing, weight loss, adenopathy and fever (Ronquillo, 1983; Londero and Ramos, 1990; Shikanai-Yasuda et al., 2006).

An early diagnosis of paracoccidioidomycosis and the immediate patient referral for treatment are important factors in reducing the number of complications caused by this disease (Araújo and Souza, 2000; Palmeiro et al., 2005). In our study, however, we found that a considerable number of patients reported a long time period between the onset of clinical symptoms and diagnosis. This delay may be related to a difficulty for health professionals in making an accurate diagnosis of PCM from early lesions as well as rural patients waiting a longer time before seeking professional help. Furthermore, the long time period between the onset of symptoms and diagnosis may also be attributed to a lack of access to health services. This long time period before diagnosis can result in PCM progressing to the residual form, which is often severe (Ronquillo, 1983; ShikanaiYasuda et al., 2006).

\section{Conclusion}

Paracoccidioidomycosis is a mycosis with an important number of reported incidences in cities of the southeast Rio-Grandense mesoregions of Rio Grande do Sul. This study highlights the need to include PCM as a differential diagnosis of respiratory infection, especially in patients with oropharyngeal lesions and in rural males from Pelotas or neighborhood cities who are between 30 and 60 years of age.

\section{References}

Almeida OP, Jacks JR, Scully C (2003) Paracoccidioidomycosis of the mouth: an emerging deep mycosis. Crit Rev Oral Biol Med 14(5):377-383.

Ameen M, Talhari C, Talhari S (2010) Advances in paracoccidioidomycosis. Clin Experimental Dermatol 35(6):576580.

Araújo MS, Souza SC (2000) Análise epidemiológica de pacientes acometidos com paracoccidioidomicose em região endêmica do Estado de Minas Gerais. Rev Pós Grad 7:22-26.

Blotta MHSL, Mamoni RL, Oliveira SJ, Nouér SA, Papaiordanou PMO, Goveia A, Camargo ZP (1999) Endemic regions of paracoccidioidomycosis in Brazil: a clinical and epidemiologic study of 548 cases in the southeast region. Am J Trop Med Hig 61:390-394.

Borges-Walmsley MI, Chen D, Shu X, Walmsley AR (2002) The phatobiology of Paracoccidioides brasiliensis. Trends Microbiol 10(2):80-87.

Bousquet A, Dussart C, Drouillard I, Charbel EC, Boiron P (2007) Mycoses d'importation: le point sur la paracoccidioidomycose. Méd Mal Infect 37:210-214.

Campos MVS, Penna GO, Castro CN, Moraes MAP, Ferreira MS, Santos JB (2008) Paracoccidioidomicose no Hospital Universitário de Brasília. Rev Soc Bras Med Trop 2:41.

Colombo AL, Tobón A, Restrepo A, Queiroz-Telles F, Nucci M (2011) Epidemiology of endemic systemic fungal infections in Latin America. Med Mycol 49:785-798.

Jannke HA, Isolan T, Pinto IO, Isaacsson JA (1982) Blastomicose sul-americana com comprometimento genital. Rev Bras Cirurgia 72(4):247-249.

Jannke HA, Lopez FS, Abrahao MC, Thofern P, Duarte AL, Holthausen ET (1983) Blastomicose sul-americana palpebral. Rev Bras Oftalmol 42(2):157-160.

Jannke HA, Deves ML, Roberti AG, Taddeu CAG, Bazzano MC, Ferreira AD, Menezes FS, Oliveira Filho UL (1993) Paracoccidioidomicose Associada a Neurofibromatose de Von Recklinghausen e Fenda Palatina. Observação de dois casos. 
XXIX Congresso da Sociedade Brasileira de Medicina Tropical 26:274.

Londero AT, Ramos CD, Lopes JO (1978) Progressive Pulmonary Paracoccidioidomycosis a study of 34 cases observed in Rio Grande do Sul (Brazil). Mycopathologia 63(1):53-56.

Londero AT, Ramos CD (1990) Paracoccidioidomicose. Estudo clínico e micológico de 260 casos observados no interior do Estado do Rio Grande do Sul. J Pneumol 1:129-132.

Marques SA (2003) Paracoccidiodomycosis: epidemiological, clinical and treatment up-date. Arq Bras Dermatol 78(2):135-150.

Palmeiro M, Cherubini K, Yurgel LS (2005) Paracoccidioidomicose-Revisão da Literatura. Scientia Medica 15(4):274278.

Paniago AMM, Aguiar JIA, Aguiar ES, Cunha RV, Pereira GRO, Londero AT, Wanke B (2003) Paracoccidioidomicose: estudo clínico e epidemiológico de 422 casos observados no Estado de Mato Grosso do Sul. Rev Soc Bras Med Trop 36(4):455-459.

Ramos E, Silva M, Saraiva, LES (2008) Paracoccidioidomycosis. Dermatol Clinics 26(2):257-269.

Richini-Pereira VB, Bosco SM, Theodoro RC, Barrozo L, Pedrini SC, Rosa PS, Bagagli E (2009) Importance of the xenar- thrans in the ecoepidemiology of Paracoccidioides brasiliensis. BMC Research Notes 2:228.

Ronquillo TEF (1983) Contribuição ao estudo da paracoccidioidomicose na República do Equador. Rev Patol Trop 12:345-419.

Santos JWA, Severo LC, Porto NS, Moreira JS, Silva LCC, Camargo JJP (1999) Chronic Pulmonary Paracoccidioidomycosis in the state of Rio Grande do Sul, Brazil. Mycopathologia 143:63-67.

Shikanai-Yasuda MA, Queiroz TL, Mendes R, Colombo A, Moretti MA (2006) Consenso em paracoccidioidomicose. Rev Soc Bras Med Trop 39:297-310.

Verli FD, Marinho SA, Souza SC, Figueiredo MAZ, Yurgel LS (2005) Perfil clínico-epidemiológico dos pacientes portadores de paracoccidioidomicose no Serviço de Estomatologia do Hospital São Lucas da Pontifícia Universidade Católica do grande do Sul. Rev Soc Bras Med Trop 38:234237.

Vieira EMM, Borsatto-Galera B (2006) Manifestações clínicas bucais da paracoccidioidomicose. Rev Patol Trop 35:23-30.

All the content of the journal, except where otherwise noted, is licensed under a Creative Commons License CC BY-NC. 